\title{
A Research on Sustainable Development in India
}

\author{
Sajjan Choudhuri
}

\begin{abstract}
This research paper is a systematic review of sustainable development initiatives in India. In this systematic review, forty articles related with sustainable development in India (2014-2019) had been reviewed from the source of multiple sources. This study found that there are only few literature regarding sustainable development initiatives in India and many of the SDG's were unexplored by the researchers. This research is concluded by identifying the SDGs of gender equality, reduction in inequality, peace and justice, and responsible consumption and production as the most promising niches for future research in the area of sustainable development initiatives in India.
\end{abstract}

Keywords: Sustainability, Sustainable Development, SDG, Sustainable Development Goals.

\section{INTRODUCTION}

Sustainable development is the key for overall prosperity of the world. The word sustainable development has many definitions and the most popular definition had been coined by report of "Brundtland", which defines sustainable development as "development that meets the needs of present without compromising the ability of future generations to meet their own needs". To achieve sustainable development of prosperity and for protecting planet by 2030, SDG, i. e Sustainable Development Goals had been developed. There are 17 SDGs and have specific targets for each. The detailed list of sustainable development goals had been given in the following list. This article has the objective of consolidating the literature on sustainable development activities in India of last two decades and to arrange them according to various SDGs. This article also aims to evaluate the progress India had made in sustainable development in last five years. This paper is divided into five parts.

Figure 1: Publications (Year wise)

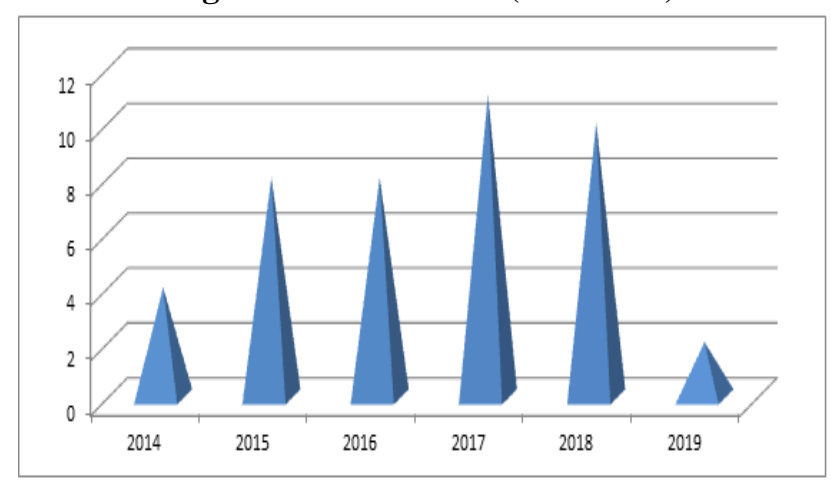

\section{REVIEW METHODOLOGY}

\subsection{Selection of Journals and proceedings}

Revised Manuscript Received on July 10, 2019.

Dr Sajjan Choudhuri, Associate Professor, Chandigarh University Punjab, India.

(e-mail sajjan.apex@gmail.com)
This study is based on only single data source, Web of Science on 10/04/2019.

\subsection{Selection of key themes for literature review}

This paper classifies all the 17 SDGs into four broad themes and the literatures had been reviewed on basis of themes and SDGs. This paper aims to find out the research gaps in themes and to identify the futuristic areas of research in the concept of sustainable development in India

\section{LITERATURE REVIEW}

\subsection{Goals of Economic Development}

With reference to SDG of "Sustainable cities", a comparative study on progress of the concept of sustainable cities in India and Germany was studied by (Koch and Ahmad 2018). The study considered the parameters of resilience, safety and inclusiveness.

With regards to SDG of "decent work and economic growth", Infrastructure is the key factor growth of any economy. The funding problem due for huge infra projects are now executed through PPP model, and the evolution, rationale, benefits and challenges of PPP model of huge infra projects like airports in India was studied by (Kaur and Prashanthi 2015). The problems and prospects of mining in India and potential of sustainable mining activities in India was studied by (Gupta and Raghuwanshi 2015). The role of urban rail in sustainable development of Indian cities was studied by (R Sharma and Newman 2017) at the same time the quality evaluation of sustainable bus services in Patna was studied by (Sinha, Sadhukhan, and Priye 2017) and sorted out the positive and negative parameters on bus quality.

\subsection{Goals on Environment}

With regards to SDG of "Life on land", the economic, social and ecological issues of four selected Forestry clean development mechanism had been studied by (Aggarwal 2014) out of which three of them were found to be economically unsustainable. The study also found that the plants used in these projects were having a number of adverse ecological and social impacts on long term. The study concluded by recommending a second thought on CDM projects in comparison with Green India Mission and REDD+ mission. The study on medicinal plant cultivation 
and sustainable development of Bengal was conducted by (Ghosh and Chatterjee 2016). The study by (Mell and Sturzaker 2014) had researched on the sustainable urban development in land constrained area of Darjeeling.

With regard to the SDG of " Life below water", the Indian initiative and progress in reduction of greenhouse gas emission with regard to targets of NDC(Nationally determined contributions) was studied by (Byravan et al. 2017) and found that India is progressing positively to the 2030 emission targets. The vulnerability of coastal districts of Tamil Nadu to the climate variability was studied with the variables of ground water, agriculture and fisheries by (Ramachandran et al. 2016). The most vulnerable variable of each district was identified and the adaptive measures to be taken for each had been given on a priority basis.

\subsection{Goals of Equality and Justice}

With regards to SDG of "Partnerships to achieve goals", Indo-China opportunities on science and technology for sustainable development of selected Himalayan regions was studied by (E. Sharma 2017). Similarly the mutual understanding and partnership between India and EU regarding green and sustainable development initiatives was studied in detail by (Prasad 2017).

With regards to the SDG of " Gender equality", the role of commercial banks in supporting women entrepreneurship and improving gender equality in doing business was studied by (Deepa 2014). With regarding the SDG of "equality", an evaluative study on empowerment of local communities of Mizoram was documented by the research of (Lalneihzovi 2015).

\subsection{Goals of Welfare}

With regard to the challenges of Civil society Organizations in sustainable agriculture in India, a study conducted by (Brown 2016) identified that apart from technological innovation, the power of state, donor organizations, activists network, rural elites and rural poor are the key factors influencing sustainable agriculture in India. The role agriculture and climate change adaptation for sustainable development of India was described by (Usman 2017).

With regards to the SDG of " Clean water and sanitation", The successfulness of using technology for assessing water potential, Geo informatics in ground water potential mapping in Micro watershed in Tirunelveli was conducted by (Narmada, Gobinath, and Bhaskarana 2015) and similar study on Amravati River basin was conducted by (Anbazhagan and Jothibasu 2016). The ground water potential of Ganga Alluvial Plain was studied by (Patra, Mishra, and Mahapatra 2018) by using remote sensing, GIS and analytical hierarchy process. The study had developed a ground water potential map by classifying areas as good, moderate and poor. At the same time the need for prioritizing the need for water sheds for sustainable development in Swan Catchment area of Himachal Pradesh was studied by (Batar, Singh, and Kumar 2016) by using the parameters of soil, drainage density, irrigated area, forest area land cover and land use, surface water and groundwater prospects etc. The study had prioritized watersheds to the categories to high priority, medium priority, very low and low priority.
However there had been arguments that the sustainability of watersheds is short run. An integrated hydrogeological study for ground water management was conducted by (Madhnure, Peddi, and Allani 2016). The water quality problems due to tannery pollutants in Palar river in South India was studied by (Sonkamble et al. 2014).

A detailed study on India's initiatives towards SDG of "clean water and sanitation" was conducted by (Roy and Pramanick 2019) by analyzing 28 parameters divided into two categories of social and biophysical. The study also found the interrelation of SDG of "water and sanity" with SDG of "Health" and SDG "poverty". The study concluded that a positive increase in sanitation indicators would improve water and sanitation related diseases.

With regards to SDG "No hunger", a study the progress, linkages and disconnects of India towards food security and nutrition was conducted by (Das, Sharma, and Babu 2018) and the study found that southern states are far better than their counter parts in the area of food security and nutrition. The study concluded by recommending for reforms in coordination and approach for achieving 2030 targets of food security and nutrition.

With regard to the SDG of "Education" The sustainability of Higher Education Institutes in India was studied by (Parvez and Agrawal 2019), after considering parameters and indicators of "STARS" and "UI Green Metric WUR" and found that around $50 \%$ parameters of the above benchmarks were not complied. The study pointed out the need for report specific rating parameters for HEI's in India.

With regards to SDG of "Energy", the challenges of conserving energy, the current mix of energy sources in India and the role of energy security and sustainable development in India was described by (Gouri 2015). The role of globalization in the energy demand in India was analyzed by (Shahbaz et al. 2016). The study conducted by (Srikanth 2018). The study results of (Kar 2015) had concluded that the natural gas would be the most preferred green energy for India in the upcoming decades. Biogas potential as an energy solution to energy basket of India was suggested in the study of (Lohan et al. 2015). The need, prospects, application and barriers of solar energy infusion into Indian energy Basket had been reviewed by (Manju and Sagar 2017). The problem of energy poverty and the impact of new energy policies, popularization of alternate fuels and associated challenges with sustainable development of energy in India had been described in the work of (Jewitt and Raman 2017).

Rural electrification is a great challenge in India, especially remote areas and the need for micro solar energy systems for facilitating rural electrification and sustainable development in rural and remote areas of North Eastern India was pointed out in the study of (Dhiman et al. 2017), after considering the challenges of remote locations, dispersed population density and high transmission cost. A much similar study quoting applicability of solar solutions for rural electrification was conducted by (Jasrotia et al. 2018). The possibilities and benefits of two hybrid energy model for rural and remote regions was studied by (Renu Sharma and Goel 2016). 
With regards to SDG of "Health and Wellbeing" the child mortality rate of India under the age of five (U5MR) was studied by (Bora and Saikia 2018) based on secondary sources and found that the National Mortality rate and U5MR is 2.4times and double higher than the targeted rates. The study had found that the North Central and eastern India are way behind in their targets. To this problem of high child mortality, the study conducted by (V Kancherla and Oakley 2017) had described the way of reducing Child mortality by controlling birth defects. A similar study of (V Kancherla and Oakley 2016)(Vijaya Kancherla and Oakley Jr. 2018) had mentioned about total prevention of folic acid preventable Bifida and Anencephaly would reduce Child Mortality in India.

The need for preventing non communicable diseases for sustainable development was highlighted in the study of (John 2018). The exclusions in health services in Kerala was studied by (Thresia 2018)

\section{ANALYSIS RESULTS OF LITERATURE REVIEW}

With regards to SDG of "Sustainable cities and communities", this study had found a few articles related with sustainable architecture and building and the areas of research were design, usage of HVFA concrete in building process and comparative study of Indian and German cities. Another area for interest of researchers were green roads, PPP model of working for airport, urban rail projects, sustainable mining and sustainable bus services.

With regards to SDG of "Life on land", most of the research was concentrated on forest products, medical and non-medical plantations and their impact on rural development. Another theme of research was the CDM, i.e. Clean Development Mechanism. Studies related with efficiencies, pitfalls and comparisons regarding CDM were conducted by researchers.

With regard to the SDG of "Life below water", the values, challenges, impact on local community of the Mangrove wet lands and coastal regulation zones in Kerala, had been reviewed researchers.

With regard to SDG of "Climate Change" the role, challenges of climate protection for sustainable development and impact of crop market in Kerala with climate change was explored by researchers. The Indian initiative and progress in reduction of greenhouse gas emission was also studied by researchers.

With regards to SDG of "Partnerships to achieve goals", the Indo China relations and India and EU relations regarding sustainable development initiatives was explored by researchers.

With regards to the SDG of "Gender equality", the role of industries in supporting women entrepreneurship and uplifting status of women folk was reviewed by researchers.

With regards to SDG of "No Poverty", the role of small check dams and lift irrigation in villages to reduce the problems of water and role of ecology and ecological poverty on the poor living conditions of Central Himalayan areas was studied by researchers. The usage of technology and terrain mapping approach for sustainable agriculture and the transition of Haryanvi Farmers to sustainable agriculture was another area for researchers.
The major applications of sustainable development activities in agriculture in rural development, the role of geology, and the role agriculture and climate change adaptation for sustainable development of India was described by thoroughly described by researchers.

With regards to the SDG of "Clean water and sanitation", the severe water crisis and irrigation problem faced by Gujarat and the role of SardarSarovar Water Resource project on improving food security, and socio economic development were some areas of research by scholars.

The successfulness of using technology for assessing water potential, like remote sensing, GIS and analytical hierarchy process and geo informatics in ground water potential mapping in Micro watershed in Tirunelveli, Amravati River basin and Ganga Alluvial Plain was studied by researchers. At the same time the need, sustainability of water sheds and integrated working model for sustainable development in Swan Catchment area of Himachal Pradesh, Mayurakshi watershed, Karondi-Milli Watershed, Maheshwaram catchment area and some other selected areas was conducted by researchers.

The water quality problems due to unplanned urbanization and industrialization in the banks of river Yamuna, Kosi and Palar and challenges it creates of sustainable development was researched by scholars.

With regards to SDG "No hunger", a study the progress, linkages and disconnects of India towards food security and nutrition was studied.

With regard to the SDG of "Education" a study on curriculum innovation, policies, challenges, prospects and future of higher education for sustainable development of India was the area of interest for researchers.

With regards to SDG of "Energy", the role, challenges of conserving energy, the current mix of energy sources in India and the prospects and future energy mix of India was explored by researchers. The role of off grid solar system, its diffusion, acceptance, need, prospects, application and barriers of solar energy infusion into Indian energy Basket had been reviewed researchers. The possibilities micro solar energy systems for facilitating rural electrification, benefits of two hybrid energy model and potential of small hydroelectric projects for electrification of rural and remote regions was studied by scholars.

With regards to SDG of "Health and Wellbeing" the child mortality rate of and solutions, the need for preventing non communicable diseases for sustainable development was studied by researchers. The role of sustainable community based health and development programmes in Rural India and use of remote sensing and GIS for improving rural health was studied by researchers

\section{FUTURISTIC RESEARCH AND CONCLUSION}

This systematic review on sustainable development practices in India had found that there is a huge gap on literature regarding sustainable development in India. Out of 17 SDGs, the SDGs of gender equality, reduction in inequality, peace and justice, partnerships to achieve goals, decent work and economic system, industry, innovation and 
infrastructure, sustainable cities and communities, responsible consumption and production are the least researched areas. There are sufficient gaps in clean energy, sanitation and linking the government plans to SDGs. There are futuristic niches in social problems of poverty, hunger, health and education. The overall status regarding existing research in this area is that there is ample scope for research in this area for researchers. However this research is limited to a single source of Web of Science and it's a limitation for this study and readers should consider other sources before going into a conclusion.

\section{REFERENCES}

1. Aggarwal, Ashish. 2014. "How Sustainable Are Forestry Clean Development Mechanism Projects?-A Review of the Selected Projects from India." MITIGATION AND ADAPTATION STRATEGIES FOR GLOBAL $\begin{array}{llll}\text { CHANGE } & 19 & \text { (1): }\end{array}$ https://doi.org/10.1007/s11027-012-9427-x.

2. Anbazhagan, S, and A Jothibasu. 2016. "Geoinformatics in Groundwater Potential Mapping and Sustainable Development: A Case Study from Southern India." HYDROLOGICAL SCIENCES JOURNAL-JOURNAL DES SCIENCES HYDROLOGIQUES 61 (6): 1109-23. https://doi.org/10.1080/02626667.2014.990966.

3. Batar, Amit Kumar, R B Singh, and Ajay Kumar. 2016. "Prioritizing Watersheds for Sustainable Development in Swan Catchment Area, Himachal Pradesh, India." In ENVIRONMENTAL GEOGRAPHY OF SOUTH ASIA: CONTRIBUTIONS TOWARD A FUTURE EARTH INITIATIVE, edited by Singh, RB and Prokop, P, 49-66. Advances in Geographical and Environmental Sciences. https://doi.org/10.1007/978-4-431-55741-8_3.

4. Bora, Jayanta Kumar, and Nandita Saikia. 2018 "Neonatal and Under-Five Mortality Rate in Indian Districts with Reference to Sustainable Development Goal 3: An Analysis of the National Family Health Survey of India (NFHS), 2015-2016." PLOS ONE 13 (7). https://doi.org/10.1371/journal.pone.0201125.

5. Brown, Trent. 2016. "Civil Society Organizations for Sustainable Agriculture: Negotiating Power Relations for pro-Poor Development in India." AGROECOLOGY AND SUSTAINABLE FOOD SYSTEMS 40 (4): 381-404.

https://doi.org/10.1080/21683565.2016.1139648.

6. Byravan, Sujatha, Mohd. Sahil Ali, Murali Ramakrishnan Ananthakumar, Nihit Goyal, Arnit Kanudia, Pooja Vijay Ramamurthi, Shweta Srinivasan, and Anantha Lakshmi Paladugula. 2017. "Quality of Life for All: A Sustainable Development Framework for India's Climate Policy Reduces Greenhouse Gas Emissions.” ENERGY FOR SUSTAINABLE DEVELOPMENT 39 (August): 48-58. https://doi.org/10.1016/j.esd.2017.04.003.

7. Das, Mousumi, Ajay Sharma, and Suresh Chandra Babu. 2018. "Pathways from Agriculture-to-Nutrition in India: Implications for Sustainable Development Goals." FOOD $\begin{array}{llll}\text { SECURITY } & 10 & \text { (6): }\end{array}$ https://doi.org/10.1007/s12571-018-0858-4.

8. Deepa, S. 2014. "Role of Commercial Banks in Sustainable Development of Women Entrepreneurs in India." PACIFIC BUSINESS REVIEW INTERNATIONAL 6 (9): 45-49.

9. Dhiman, Brajesh, Mrinal Krishna Chaudhury, Sudip Kumar Deb, and Debkumar Chakrabarti. 2017. "Micro Solar Energy Systems: Product Design Intervention Facilitating Sustainable Development for Rural North East India." In RESEARCH INTO DESIGN FOR COMMUNITIES, VOL 2: PROCEEDINGS OF ICORD 2017, edited by Chakrabarti, A and Chakrabarti, D,
66:117-25. Smart Innovation Systems and Technologies https://doi.org/10.1007/978-981-10-3521-0_10.

10. Ghosh, M, and S K Chatterjee. 2016. "Sustainable Development of Medicinal and Aromatic Plants as Potential Cash Crops for the Welfare of Rural People in Eastern India." In XXIX INTERNATIONAL HORTICULTURAL CONGRESS ON HORTICULTURE:SUSTAINING LIVES,LIVELIHOODS AND LANDSCAPES:V WORLD CONGRESS ON MEDICINAL AND AROMATIC PLANTS AND INTERNATIONAL SYMPOSIUM ON PLANTS AS FACTORIES OF NATURAL SUBSTANCES,EDIBLE AND ESSENTIAL OILS, edited by Patil, B and Gafner, S and Craker, L and Mentreddy, SR, 1125:201-7. Acta Horticulturae. https://doi.org/10.17660/ActaHortic.2016.1125.25.

11. Gouri, K Vasantha. 2015. "Energy Security and Sustainable Development: A Case of India." In PROCEEDINGS OF 2015 INTERNATIONAL

CONFERENCE ON PUBLIC ADMINISTRATION (11TH) VOL I, edited by Zhu, X and Zhao, S, 73-80.

12. Gupta, D C, and R S Raghuwanshi. 2015. "Exploration for Sustainable Development of India's Mineral Resources: Problems and Prospects: Dr.BPRadhakrishna Commemorative Volume." JOURNAL OF THE GEOLOGICAL SOCIETY OF INDIA 85 (6): 753. https://doi.org/10.1007/s12594-015-0272-x.

13. Jasrotia, Shivakshi, Arun Kansal, Madhuben Sharma, and Swati Gupta. 2018. "Application of Sustainable Solar Energy Solutions for Rural Development-A Concept for Remote Villages of India." In ADVANCES IN HEALTH AND ENVIRONMENT SAFETY, edited by Siddiqui, NA and Tauseef, SM and Bansal, K, 209-17. Springer Transactions in Civil and Environmental Engineering. https://doi.org/10.1007/978-981-10-7122-5_21.

14. Jewitt, Sarah, and Sujatha Raman. 2017. "Energy Poverty, Institutional Reform and Challenges of Sustainable Development: The Case of India." PROGRESS IN $\begin{array}{llll}\text { DEVELOPMENT STUDIES } 17 & \text { (2): 173-85 }\end{array}$ https://doi.org/10.1177/1464993416688837.

15. John, S. 2018. "NCD Prevention: A Pathway to India's Sustainable Development." TOBACCO INDUCED DISEASES 16 (1): 4. https://doi.org/10.18332/tid/83856.

16. Kancherla, V, and G Oakley. 2017. "Achieving Reductions in Child Mortality by Preventing Birth Defects in India and Reaching Sustainable Development Goals.” BIRTH DEFECTS RESEARCH 109 (9, SI): 641.

17. Kancherla, V, and G P Oakley. 2016. "Contribution of Total Prevention of Folic Acid Preventable Spina Bifida and Anencephaly towards Achieving Health-Related Sustainable Development Goals in India.” BIRTH DEFECTS RESEARCH PART A-CLINICAL AND MOLECULAR TERATOLOGY 106 (5, SI): 399

18. Kancherla, Vijaya, and Godfrey P Oakley Jr. 2018. "Total Prevention of Folic Acid-Preventable Spina Bifida and Anencephaly Would Reduce Child Mortality in India: Implications in Achieving Target 3.2 of the Sustainable Development Goals." BIRTH DEFECTS RESEARCH 110 (5): 421-28. https://doi.org/10.1002/bdr2.1175.

19. Kar, Sanjay Kumar. 2015. "Natural Gas to Drive Green and Sustainable Developments in India." In ENERGY SUSTAINABILITY THROUGH GREEN ENERGY, edited by Sharma, A and Kar, SK, 385-426. Green Energy and Technology. https://doi.org/10.1007/978-81-322-2337-5_15. 
20. Kaur, Ravinder, and G Prashanthi. 2015. "Public Private Partnerships as a Sustainable Strategy for Infrastructure Development: A Case of India." In PROCEEDINGS OF 2015 INTERNATIONAL CONFERENCE ON PUBLIC ADMINISTRATION (11TH) VOL I, edited by Zhu, X and Zhao, S, 108-14.

21. Koch, Florian, and Sohail Ahmad. 2018. "How to Measure Progress Towards an Inclusive, Safe, Resilient and Sustainable City? Reflections on Applying the Indicators of Sustainable Development Goal 11 in Germany and India." In URBAN TRANSFORMATIONS: SUSTAINABLE URBAN DEVELOPMENT THROUGH RESOURCE EFFICIENCY, QUALITY OF LIFE AND RESILIENCE, edited by Kabisch, $\mathrm{S}$ and Koch, $\mathrm{F}$ and Gawel, E and Haase, A and Knapp, S and Krellenberg, K and Nivala, J and Zehnsdorf, A, 10:77-90. Future City. https://doi.org/10.1007/978-3-319-59324-1_5.

22. Lalneihzovi. 2015. "Empowerment of Local Communities in India for Sustainable Development: A Case Study of Mizoram.” In PROCEEDINGS OF 2015 INTERNATIONAL CONFERENCE ON PUBLIC ADMINISTRATION (11TH) VOL I, edited by Zhu, X and Zhao, S, 130-36.

23. Lohan, Shiv Kumar, Jagvir Dixit, Rohitashw Kumar, Yogesh Pandey, Junaid Khan, Mohd. Ishaq, Sheikh Modasir, and Dinesh Kumar. 2015. "Biogas: A Boon for Sustainable Energy Development in India's Cold Climate." RENEWABLE \& SUSTAINABLE ENERGY REVIEWS 43 (March): 95-101. https://doi.org/10.1016/j.rser.2014.11.028.

24. Madhnure, Pandith, Nageshwar Rao Peddi, and Damodar Rao Allani. 2016. "An Integrated Hydrogeological Study to Support Sustainable Development and Management of Groundwater Resources: A Case Study from the Precambrian Crystalline Province, India." HYDROGEOLOGY JOURNAL 24 (2): 475-87. https://doi.org/10.1007/s10040-015-1342-2.

25. Manju, S, and Netramani Sagar. 2017. "Progressing towards the Development of Sustainable Energy: A Critical Review on the Current Status, Applications, Developmental Barriers and Prospects of Solar Photovoltaic Systems in India." RENEWABLE \& SUSTAINABLE ENERGY REVIEWS 70 (April): 298-313. https://doi.org/10.1016/j.rser.2016.11.226.

26. Mell, Ian C, and John Sturzaker. 2014. "Sustainable Urban Development in Tightly Constrained Areas: A Case Study of Darjeeling, India." INTERNATIONAL JOURNAL OF URBAN SUSTAINABLE $\begin{array}{lll}\text { DEVELOPMENT } & 6 & (1):\end{array}$ https://doi.org/10.1080/19463138.2014.883994.

27. Narmada, K, K Gobinath, and G Bhaskarana. 2015. “An Assessment of Resource Potentials For Sustainable Development of Micro-Watershed In Tirunelveli District Using Geoinformatics- A Case Of Nambiyar Micro-Watershed In Tirunelveli District, Tamil Nadu, India." In INTERNATIONAL CONFERENCE ON WATER RESOURCES, COASTAL AND OCEAN ENGINEERING (ICWRCOE'15), edited by Dwarakish, GS, 4:1299-1306. Aquatic Procedia. https://doi.org/10.1016/j.aqpro.2015.02.169.

28. Parvez, Nikhat, and Avlokita Agrawal. 2019. "Assessment of Sustainable Development in Technical Higher Education Institutes of India." JOURNAL OF CLEANER PRODUCTION 214 (March): 975-94. https://doi.org/10.1016/j.jclepro.2018.12.305.

29. Patra, Suman, Pulak Mishra, and Subhash Chandra Mahapatra. 2018. "Delineation of Groundwater Potential Zone for Sustainable Development: A Case Study from Ganga Alluvial Plain Covering Hooghly District of India
Using Remote Sensing, Geographic Information System and Analytic Hierarchy Process." JOURNAL OF CLEANER PRODUCTION 172 (January): 2485-2502. https://doi.org/10.1016/j.jclepro.2017.11.161.

30. Prasad, Kiran. 2017. "From Grey to Green: Sustainable Development Perspectives From India-EU Partnerships." In HANDBOOK OF RESEARCH ON POLICIES AND PRACTICES FOR SUSTAINABLE ECONOMIC GROWTH AND REGIONAL DEVELOPMENT, 177-86. Advances in Finance Accounting and Economics.

https://doi.org/10.4018/978-1-5225-2458-8.ch016.

31. Ramachandran, A, Dhanya Praveen, P Radhapriya, S K Divya, K Remya, and K Palanivelu. 2016. "Vulnerability and Adaptation Assessment a Way Forward for Sustainable Sectoral Development in the Purview of Climate Variability and Change: Insights from the Coast of Tamil Nadu, India." INTERNATIONAL JOURNAL OF GLOBAL WARMING 10 (1-3, SI): 307-31. https://doi.org/10.1504/IJGW.2016.10000051.

32. Roy, Ajishnu, and Kousik Pramanick. 2019. "Analysing Progress of Sustainable Development Goal 6 in India: Past, Present, and Future." JOURNAL OF ENVIRONMENTAL MANAGEMENT 232 (February): 1049-65. https://doi.org/10.1016/j.jenvman.2018.11.060.

33. Shahbaz, Muhammad, Hrushikesh Mallick, Mantu Kumar Mahalik, and Perry Sadorsky. 2016. "The Role of Globalization on the Recent Evolution of Energy Demand in India: Implications for Sustainable Development." ENERGY ECONOMICS 55 (March): 52-68. https://doi.org/10.1016/j.eneco.2016.01.013.

34. Sharma, Eklabya. 2017. "China-India Collaborative Opportunities on Science and Technology for Sustainable Development of the Hindu Kush Himalaya." SCIENCE BULLETIN 62 (10): 673-74. https://doi.org/10.1016/j.scib.2017.03.007.

35. Sharma, R, and P Newman. 2017. "Urban Rail and Sustainable Development Key Lessons from Hong Kong, New York, London and India for Emerging Cities." In Transportation Research Procedia, 26:92-105. https://doi.org/10.1016/j.trpro.2017.07.011.

36. Sharma, Renu, and Sonali Goel. 2016. "Stand-Alone Hybrid Energy System for Sustainable Development in Rural India." ENVIRONMENT DEVELOPMENT AND SUSTAINABILITY $18 \quad$ (6): $1601-14$ https://doi.org/10.1007/s10668-015-9705-3.

37. Sinha, Sanjeev, Shubhajit Sadhukhan, and Shiv Priye. 2017. "The Role of Quality Assessment for Development of Sustainable Bus Service in Mid-Sized Cities of India: A Case Study of Patna." In URBAN TRANSITIONS CONFERENCE, edited by Seto, K and Robinson, D and Virji, $\mathrm{H}$ and Kovacs, $\mathrm{Z}$ and Zhai, J and Sami, $\mathrm{N}$ and Pettit, C and Sridhar, KS, 198:926-34. Procedia Engineering. https://doi.org/10.1016/j.proeng.2017.07.138.

38. Sonkamble, Sahebrao, V Satish Kumar, B Amarender, P M Dhunde, S Sethurama, and K Raj Kumar. 2014. "Delineation of Fresh Aquifers in Tannery Belt for Sustainable Development - A Case Study from Southern India." JOURNAL OF THE GEOLOGICAL SOCIETY $\begin{array}{llll}\text { OF } & \text { INDIA } & 83 & (3):\end{array}$ https://doi.org/10.1007/s12594-014-0040-3.

39. Srikanth, R. 2018. "India's Sustainable Development Goals - Glide Path for India's Power Sector.” ENERGY POLICY 123 (December): 325-36. https://doi.org/10.1016/j.enpol.2018.08.050.

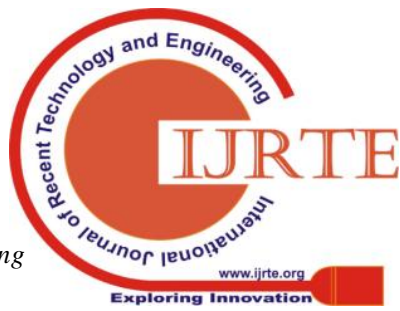


40. Thresia, C U. 2018. "Health Inequalities in South Asia at the Launch of Sustainable Development Goals: Exclusions in Health in Kerala, India Need Political Interventions." INTERNATIONAL JOURNAL OF HEALTH SERVICES 48 (1): 57-80. https://doi.org/10.1177/0020731417738222.

41. Usman, Adil. 2017. "Sustainable Development Through Climate Change Mitigation and Biomass Agriculture: India's Perspective." In 2017 IEEE CONFERENCE ON TECHNOLOGIES FOR SUSTAINABILITY (SUSTECH 2017), 20-26. 